\title{
Triggering Receptor Expressed On Myeloid Cells 2
}

National Cancer Institute

\section{Source}

National Cancer Institute. Triggering Receptor Expressed On Myeloid Cells 2. NCI

Thesaurus. Code C125470.

Triggering receptor expressed on myeloid cells 2 ( $230 \mathrm{aa}, \sim 25 \mathrm{kDa}$ ) is encoded by the human TREM2 gene. This protein plays a role in macrophage and dendritic cell immune responses. 